\title{
Faktor-Faktor Bioekologi pada Komitmen Pernikahan Tenaga Kerja Wanita Asal Indramayu
}

\author{
Melok Roro Kinanthi ${ }^{1}$, Adriana Ginanjar ${ }^{2}$, Winarini Wilman ${ }^{3}$ \\ ${ }^{1}$ Universitas YARSI, Jl. Letjend Suprapto No.1, Jakarta Pusat \\ ${ }^{2,3}$ Universitas Indonesia, Jl. Lkr. Kampus Raya Blok Mawar No.5, Kota Depok \\ e-mail: melok.roro@yarsi.ac.id
}

\begin{abstract}
Abstrak
The aim of this study was to explore ecological factors that contribute to marital commitment of the female migrant workers in Indramayu. This study applied qualitative approach with case study design. Data were obtained by semi structure interview, focus group discussion, observation, and document analysis. This study was conducted in Village $X$ because this village is one of the biggest contributors of female migrant workers. Participants of this study were female migrant workers, government's institution staff, villagers, who were selected by purposive sampling method. The finding of this study shows that the dynamic of marital relation among female migrant workers were the result of dynamic interaction bertween macrosystem, exosystem, mesosystem, and microsystem context. Thus, the intervention should be done not only in dyadic context, but also should be directed in macro context.
\end{abstract}

Keywords / Kata kunci

\begin{abstract}
Tujuan penelitian ini adalah mengeksplorasi faktor-faktor bioekologi yang mungkin berkontribusi terhadap komitmen pernikahan Tenaga Kerja Wanita (TKW) Indramayu. Penelitian ini menggunakan pendekatan kualitatif dengan desain studi kasus. Data diperoleh dengan melakukan wawancara semi terstruktur, diskusi kelompok terfokus, observasi, dan analisis dokumen. Penelitian ini dilakukan di Desa X dengan pertimbangan desa tersebut merupakan salah satu basis pengiriman TKW terbanyak di Indramayu. Partisipan yang terlibat dalam penelitian ini adalah TKW, aparat pemerintah, dan warga Desa X, yang dipilih menggunakan metode purposive sampling. Hasil penelitian menunjukkan bahwa dinamika relasi pernikahan TKW merupakan hasil interaksi yang dinamis dari lingkungan makrosistem, eksosistem, mesosistem, maupun mikrosistem. Dengan demikian, intervensi terhadap relasi pernikahan TKW asal Indramayu tidak hanya dilakukan dalam konteks dyadic, namun dapat pula diarahkan pada konteks makro.
\end{abstract}

Bioecology theory Female Migrant Worker Marital Commitment Marital Relation

\section{Pendahuluan}

Jumlah perceraian di Indramayu merupakan yang tertinggi di Indonesia. Pada tahun 2017, Pengadilan Agama Kabupaten Indramayu menangani sekitar 7.665 kasus perceraian. Jumlah tersebut mengalami peningkatan dibandingkan tahun 2016 yang hanya berjumlah 7.594 kasus perceraian (pikiran-rakyat.com, 26 Juni 2018). Data menunjukkan kasus perceraian yang terjadi di Indramayu didominasi oleh gugat cerai yang diajukan oleh tenaga kerja wanita atau TKW (Koran Sindo, 27 September 2013). Pada umumnya penyebab TKW melakukan gugat cerai pada suaminya adalah karena kekecewaan atas perilaku suami yang tidak bijaksana dalam menggunakan uang hasil kerja istri dan menikah lagi (Republika, 3 Oktober 2016).

Indramayu bukan saja merupakan daerah dengan tingkat perceraian tertinggi di Indonesia (Republika, 3 Oktober 2016), tapi juga merupakan 'pengekspor' TKW terbanyak kedua di Indonesia (Tribunnews.com, 9 Januari 2014). Meski di satu sisi migrasi yang dilakukan TKW dapat meningkatkan kesejahteraan ekonomi, namun di sisi lain hal ini juga membawa dampak psikososial. Salah satu dampak psikososial yang ditimbulkan dari 
bermigrasinya para istri untuk bekerja di luar negeri ini adalah konflik atau perselisihan pernikahan. Berbagai temuan penelitian menunjukkan migrasi yang dilakukan TKW turut berperan dalam menyebabkan terjadinya perceraian melalui persoalan yang muncul ketika mereka menjalani pernikahan jarak jauh dengan pasangannya (Hakim, 2003; Rosadi, 2010). Hal ini didukung oleh temuan di lapangan, seperti yang telah dipaparkan pada paragraf sebelumnya, yakni tingginya tingkat gugat cerai yang diajukan TKW di Pengadilan Agama Kabupaten Indramayu (Republika, 3 Oktober 2016). Meski demikian, berdasarkan hasil studi literatur, migrasi bukan merupakan faktor tunggal penyebab maraknya perceraian TKW Indramayu, melainkan terdapat pertalian dengan faktorfaktor sosial-budaya lainnya seperti kemiskinan struktural (Soedijar, 2014), kemiskinan kultural (Soedijar, 2014), pandangan dan kebiasaan masyarakat terkait perempuan dan pernikahan (Soekarba \& Kenyowati, 2011; Jones, Asari, \& Djuartika, 1994), pernikahan dini dan kawin paksa (Jones dkk., 1994), serta rendahnya kualitas pernikahan (Rosadi, 2010).

Ahli menyebutkan keputusan individu untuk mengakhiri atau tetap mempertahankan pernikahannya berkaitan erat dengan konsep komitmen pernikahan (Givertz, Hanzal, \& Segrin, 2009). Rendahnya komitmen pernikahan akan berdampak pada ketidakstabilan relasi pernikahan (Impett dkk., 2001), yang mana hal tersebut dapat menyebabkan gangguan psikologis, akademis, kesehatan, dan sosial pada anak (Frisco, Muller, \& Frank, 2007; Ham, 2003; Hango \& Housekencht, 2005; Sun \& Li, 2002). Mengingat betapa signifikannya dampak ketidakstabilan pernikahan bagi anggota keluarga, maka kajian mengenai komitmen pernikahan menjadi sedemikian penting dilakukan. Secara lebih spesifik, temuan penelitian ini diharapkan dapat membantu memahami latar belakang TKW dalam berkomitmen atau mengakhiri pernikahannya. Dari pengamatan peneliti, kajian tentang TKW lebih banyak diarahkan pada perlindungan hukum serta kurang menitikberatkan pada upaya peningkatan kualitas pernikahan TKW, padahal perceraian TKW mendominasi kasus perceraian di sejumlah daerah di Indonesia. Penelitian ini diharapkan menjadi salah satu kajian yang mengangkat sisi lain dari fenomena migrasi yang belum banyak dibahas dan dapat memberikan kontribusi konseptual dalam perumusan kebijakan oleh pemangku kebijakan dalam hal pembinaan kehidupan keluarga dan peningkatan kualitas pernikahan TKW.

Komitmen merupakan intensi individu untuk tetap mempertahankan relasi romantisnya (termasuk pernikahan) meski terjadi fluktuasi tingkat kepuasan dalam relasi tersebut (Jones, Adams, Moore, \& Berry, 1995). Komitmen melibatkan komponenkomponen kognitif (adanya orientasi jangka panjang), komponen konatif (keinginan untuk bertahan), dan komponen afektif (kelekatan psikologis) (Agnew, Van Lange, Rusbult, \& Langston, 1998; Arriaga \& Agnew, 2001; Drigotas, Rusbult, \& Verrette, 1999). Berbagai penelitian tentang komitmen pernikahan yang dilakukan sebelumnya, baik di dalam atau luar negeri, cenderung melibatkan perspektif pasangan suami istri (pasutri) atau salah satu pihak (suami atau istri saja). Sebagai contoh, komitmen pernikahan pada populasi masyarakat di daerah tertentu ternyata masih terkait dengan kepuasan pernikahan (Suhardono, 1998; Wismanto, 2004), selain besarnya investasi yang telah ditanamkan dan ketersediaan pasangan alternatif (Farida, 2001). Berdasarkan temuan lain didapati bahwa munculnya sesuatu yang dianggap sebagai cost dalam relasi, seperti poligami, perselingkuhan pasangan, dan kekerasan dalam rumah tangga (KDRT) dapat menyebabkan individu mengakhiri pernikahannya (Prianto, Wulandari, \& Rahmawati, 2003; Hapsari \& Iqbal, 2011, Khumas, 2012; Fauzi, 2014). Penelitian lainnya pada umumnya mengaitkan komitmen pernikahan dengan faktor-faktor individual seperti pemaafan (Firdaus, 2005; 
Imelda, 2004), kesediaan berkorban (Wismanto, 2004), religiusitas (Salman, 2010), dan coping (Peddyastri, 2005; Rahmatika \& Handayani, 2011). Di luar negeri, penelitian tentang komitmen pernikahan dilakukan dengan mengkorelasikan variabel tersebut dengan variabelvariabel seperti kepribadian (Ehrenberg dkk., 2009), attachment style (Birnie dkk., 2009), religiusitas (Algood dkk., 2009; Nelson dkk., 2011), motivasi untuk mempertahankan relasi dan motivasi untuk melakukan aktivitas relasional dengan pasangan (Gaine \& La Guardia, 2009), dan ketersediaan pasangan alternatif (Follingstad dkk., 2012). Selain itu, kajian komitmen pernikahan di negara Barat maupun di Indonesia cenderung mengacu pada perspektif transaksional antara suami dengan istri.

Meski faktor individual dan interaksional dengan pasangan berkontribusi terhadap dinamika komitmen pernikahan pada pasutri di Indonesia, misalnya seperti yang terdapat dalam hasil penelitian Prianto dkk. (2003), Hapsari dan Iqbal (2011), dan lainnya, namun pernikahan di Indonesia tidak dapat dipisahkan dari konteks masyarakat, kelompok budaya, dan keluarga besar. Sebagai contoh, orangtua memiliki peran dalam memaksa anaknya melakukan pernikahan dini (Anisa, Ramani, \& Prasetyowati, 2015) atau dalam upaya perjodohan (Ningsih \& Handoyo, 2015). Selain itu, keluarga besar atau keluarga batih masih memegang peranan penting dalam pengasuhan anak (Wahyuni \& Abidin, 2015). Keluarga besar, dalam hal ini umumnya orangtua, juga ikut turut campur dalam konflik suami istri, yakni dengan mendorong salah satu pihak untuk mengakhiri pernikahan (Hapsari \& Iqbal, 2011). Dalam konteks yang lebih luas, budaya juga berperan dalam pernikahan individu. Sebagai contoh, ditemukan bahwa pernikahan usia dini (15-19 tahun) lebih banyak terjadi di desa dibandingkan di kota (Fadlyana \& Larasati, 2009). Hal ini mengindikasikan bahwa relasi pernikahan di Indonesia tidak dapat dipisahkan dari faktor-faktor individual, interaksi pasangan, dan konteks lingkungan yang mengelilinginya. Dengan demikian, adalah penting untuk juga mempertimbangkan faktor bioekologi dalam mengkaji dinamika komitmen pernikahan, khususnya di Indramayu yang penuh dengan persoalan sosial budaya. Dengan demikian, tujuan penelitian ini adalah mengeksplorasi faktorfaktor bioekologi atau sosial budaya yang mungkin berkontribusi terhadap komitmen pernikahan TKW di Indramayu. Penelitian ini akan dilakukan di Desa X di Indramayu yang merupakan basis pengiriman TKW.

\section{Kondisi Bioekologi Indramayu}

Indramayu adalah sebuah kabupaten di propinsi Jawa Barat yang wilayahnya terletak di pesisir pantai utara Jawa. Berdasarkan laporan BPS (Badan Pusat Statistik) tahun 2015, jumlah penduduk Indramayu adalah sebesar 1.718.495 jiwa. Mata pencarian utama penduduk di wilayah ini adalah nelayan, petani, dan pekerja migran. Meski terletak di wilayah Jawa Barat, Indramayu dipengaruhi oleh budaya Jawa (Kasim, 2010). Pengaruh ini terlihat dalam bahasa, historis, penataan kota, serta arsitektur rumah (Kasim, 2010).

Sebagai wilayah yang terletak di pesisir pantai dan sekaligus agraris, masyarakat Indramayu dilingkupi oleh budaya nelayan maupun budaya petani dalam menjalani kehidupannya. Kasim (2010) menyebutkan bahwa kedua budaya tersebut memiliki karakteristik yang saling bertolak belakang. Perbedaan tersebut teletak pada gaya hidup sehari-hari. Berbeda dengan masyarakat petani, masyarakat nelayan cenderung menghabiskan uang yang dimiliki tanpa menyisihkannya untuk persediaan. Kasim (2010) melihat gejala ini sebagai perilaku konsumtif yang timbul karena adanya anggapan di kalangan nelayan bahwa musim panen terjadi setiap waktu, yakni setiap kali mereka pergi melaut, mereka akan mendapatkan hasil. Mereka seolah lupa akan adanya musim paceklik di laut, yang biasa disebut 'musim baratan' dan 'musim timuran' (Kasim, 2010). Tidak adanya persiapan untuk menghadapi musim 
paceklik membuat nelayan terpaksa menjual barang apapun yang dimiliki untuk bertahan hidup ketika musim paceklik tiba. Inilah fenomena yang diistilahkan masyarakat setempat dengan 'cul dayung, adol sarung', yang artinya 'lepas dayung (tidak melaut), terpaksa menjual sarung' (Kasim, 2010). Berbeda dengan gaya hidup nelayan yang demikian, gaya hidup petani cenderung hemat, penuh perhitungan dan matang dalam membelanjakan uang yang diperoleh. Hal ini disebabkan oleh adanya anggapan di kalangan petani bahwa panen hanya terjadi satu kali dalam setahun. Untuk itu mereka harus dapat mengelola uang hasil panen agar cukup hingga panen berikutnya.

Hal lainnya, Indramayu merupakan wilayah yang masih berkutat dengan masalah-masalah sosial budaya seperti yang terkait dengan kemiskinan karena gaya hidup konsumtif. Tingkat pendidikan masyarakat Indramayu juga masih rendah karena mereka merasa tidak memerlukan pendidikan dan masih menganggap pendidikan sebagai beban ekonomi (PikiranRakyat.com, 11 Nopember 2016). Kemudian, orangtua di Indramayu cenderung ingin segera menikahkan anak perempuannya, seringnya di usia yang masih sangat muda, agar beban ekonominya berkurang. Dengan segera menikahkan anak perempuannya, mereka merasa tidak lagi harus memenuhi kebutuhan hidup anak perempuannya tersebut (Djohar, 2006). Menurut Djohar (2006) norma sosial yang berlaku di kawasan pedesaan Indramayu adalah ketika anak perempuan sudah dinikahkan, maka ia tidak lagi menjadi tanggung jawab orangtua.

Dari sisi kehidupan bermasyarakat, Soedijar (2004) menyebutkan bahwa masyarakat Indramayu merupakan masyarakat yang gemar menyelenggarakan pesta ('hajatan'), baik yang sifatnya pribadi (seperti khitanan, pernikahan, rasulan, tujuh bulanan, 'anak tunggal') maupun yang berupa tradisi daerah (seperti Nadran, Ngarot, 'Mapag Sri, Pasar Jaringan, Dombret). Soedijar (2004) melihat berbagai pesta yang membutuhkan biaya yang tidak sedikit tersebut sebagai manifestasi dari solidaritas sosial sekaligus menjaga martabat atau harga diri individu dalam hidup bermasyarakat. Menurut Soedijar (2004) adanya tradisi hajatan tersebut cenderung memotivasi masyarakat, khususnya yang tidak mampu secara materi, untuk mencari jalan pintas demi mendapatkan uang, antara lain dengan menjadi TKW.

\section{Teori Bioekologi dari Bronfenbrenner}

Mengingat fokus penelitian ini adalah mengeksplorasi faktor-faktor bioekologi yang mungkin berkontribusi terhadap komitmen pernikahan TKW Indramayu, maka diperlukan suatu kerangka teori yang juga mempertimbangkan konteks lingkungan di dalamnya. Kerangka teori yang dimaksud adalah teori Bioekologi, yang dikembangkan oleh Bronfenbrenner (2005). Menurut teori ini, perkembangan individu merupakan hasil dari interaksi antara karakteristik personal dengan lingkungannya (mikrosistem, mesosistem, eksosistem, makrosistem). Ada dua proposisi dalam teori ini. Proposisi pertama yakni perkembangan manusia terjadi melalui proses interaksi timbal balik antara individu dengan orang, objek dan simbol di dalam lingkungan dekat, atau yang dinamakan proximal process (Bronfenbrenner \& Morris, 2006). Proposisi kedua yaitu bentuk, kekuatan, isi dan arah proximal process dalam memengaruhi perkembangan bervariasi secara sistematik sebagai fungsi dari karakteristik individu, lingkungan dimana proses terjadi, hasil perkembangan dan kontinuitas serta perubahan sosial yang terjadi sepanjang perjalanan hidup dan periode sejarah dimana individu hidup (Bronfenbrenner \& Morris, 2006). Berlangsungnya proximal process dipengaruhi oleh karakteristik personal individu (person) dan konteks lingkungan yang mengelilingi individu (context) yakni mikrosistem, mesosistem, eksosistem, dan makrosistem (Lewthwaite, 2011). 


\section{Metode}

Penelitian ini mengunakan pendekatan kualitatif dengan desain studi kasus. Dalam penelitian ini, peneliti memilih sejumlah informan dan partisipan yang dianggap dapat memberikan informasi yang bernilai mengenai komitmen pernikahan pada TKW di Desa X, Indramayu, yakni TKW, perangkat desa, perwakilan instansi pemerintah, budayawan dan sejumlah warga setempat. Nama narasumber dalam penelitian ini disamarkan. Partisipan penelitian ditentukan melalui snowball sampling. Adapun metode pengumpulan data yang digunakan adalah wawancara semi terstruktur dan mendalam, pengamatan partisipatif dan analisis dokumen.

Dalam proses pengambilan data penelitian, peneliti tinggal di rumah gatekeeper maupun seorang partisipan penelitian yang bernama Tarsih (bukan nama sebenarnya) di Desa X, Indramayu. Selama tinggal di tempat tersebut, peneliti ikut melakukan sejumlah aktivitas bersama seperti menenangga (berkumpul dengan tetangga sekitar di teras rumah sambil berbincang), membersihkan rumah, belanja ke pasar, dan sebagainya. Hal ini bertujuan mendekatkan peneliti dengan atmosfer penelitian dan mencairkan hubungan peneliti dengan partisipan.

Melalui bantuan gate keeper, peneliti mengidentifikasi pihak-pihak yang berpotensi menjadi sumber data dan membangun rapport dengan mereka. Setelah rapport terjalin, peneliti menggali informasi mengenai kondisi makrosistem, eksosistem, mesosistem, dan mikrosistem. Selain itu, peneliti juga menggali tentang dinamika kehidupan TKW dan tantangan yang dihadapi. Proses penggalian informasi dilakukan melalui wawancara kelompok dan wawancara individual, sebagai instrumen utama penelitian ini. Wawancara pada umumnya berlangsung antara 1-1.5 jam, dengan fleksibilitas struktur pertanyaan penelitian mengenai topik yang digali.

Data yang telah dikumpulkan kemudian diolah dengan teknik analisis data yang dikemukakan oleh Miles, Huberman, dan Saldana (1994). Mengacu pada teknik analisis data tersebut, pertama peneliti melakukan pengkodean terhadap data (coding). Potongan data yang telah dikode tersebut kemudian dikelompokkan ke dalam kategori-kategori atau tema-tema (pattern codes). Dalam proses ini, peneliti juga menuliskan pemikiran yang muncul pada saat menganalisis data yang ada (jotting). Peneliti kemudian menyusun pemikiran-pemikiran yang muncul tersebut ke dalam penjelasan yang koheren dan menyajikannya mengacu pada pokok-pokok teori Bioekologi.

\section{Hasil}

\section{Profil Desa X}

Desa $\mathrm{X}$ merupakan sebuah desa pesisir yang terletak di Kecamatan Juntinyuat, Kabupaten Indramayu, Provinsi Jawa Barat. Desa ini berjarak $17 \mathrm{~km}$ dari pusat Kota Indramayu. Berdasarkan data Badan Pusat Statistik Kabupaten Indramayu tercatat penduduk Desa X pada tahun 2012 berjumlah 13.204 jiwa. Sebagian besar penduduk memiliki tingkat pendidikan Sekolah Dasar dan Sekolah Menengah Pertama. Banyak penduduk yang tidak dapat melanjutkan sekolah ke jenjang berikutnya karena keterbatasan biaya. Selain karena ketiadaan biaya, hal lain yang membuat tingkat pendidikan warga Desa $\mathrm{X}$ rendah adalah karena mereka menganggap sekolah sebagai hal yang percuma, sebab pada akhirnya hanya akan menjadi TKW.

Berdasarkan data dari Badan Pusat Statistik Indramayu (2012), mayoritas penduduk Desa X menganut agama Islam, yakni sebanyak 13.200 orang (99\%). Sementara itu, hanya empat orang saja yang menganut agama Kristen Protestan, serta tidak ada yang menganut agama Katolik, Hindu, Budha, dan Kong $\mathrm{Hu} \mathrm{Cu}$. Menurut Supali Kasim, budayawan setempat, secara umum dalam hal keagamaan, kultur desa di Indramayu dapat dikategorikan sebagai desa abangan maupun desa santri. Desa abangan merupakan desa yang penduduknya tidak menjalankan syariat agama yang dipeluknya, sementara desa santri adalah 
sebaliknya. Dalam wawancaranya dengan peneliti, Kasim menyebutkan, secara umum Desa $\mathrm{X}$ digolongkan sebagai desa santri maupun abangan. Wilayah timur Desa $\mathrm{X}$ merupakan desa santri, sementara wilayah baratnya merupakan desa abangan.

Terletak di pesisir pantai utara Jawa, $80 \%$ penduduk Desa $\mathrm{X}$ bekerja sebagai nelayan dan umumnya mengandalkan laut sebagai sumber nafkahnya. Sementara itu, penduduk lainnya menekuni beragam profesi, seperti buruh tani, tukang becak, buruh di tempat penjemuran ikan, pekerja serabutan, calo TKW, atau pedagang.

\section{Gambaran Kehidupan Sosial Desa X}

Gaya Hidup Konsumtif. Dalam wawancaranya dengan peneliti (28 September 2013), Supali Kasim, budayawan Indramayu yang pernah tinggal di Desa $\mathrm{X}$ menuturkan, berbeda dengan kultur masyarakat petani yang cenderung hemat dalam membelanjakan uang, masyarakat nelayan cenderung boros dan tidak memikirkan hari esok dalam mengelola keuangan. Menurutnya, hal ini antara lain disebabkan adanya pandangan yang dianut oleh masyarakat nelayan yakni 'musim panen terjadi setiap hari', dimana setiap kali melaut nelayan merasa akan mendapat ikan (wawancara personal, 28 September 2013). Apa yang dituturkan oleh Supali Kasim tersebut sesuai dengan kecenderungan warga Desa X. Seorang narasumber menuturkan, jika sedang memiliki uang, warga Desa X gemar membeli apa saja, menghabiskan uang saat itu juga, dan tidak berpikir menyimpannya untuk memenuhi kebutuhan esok hari. Adapun sikap ini juga tercermin dalam keharusan melakukan resepsi pernikahan bagi pasangan suami istri yang menikah, terutama bagi mereka yang pernah bekerja sebagai TKW. Mereka tidak mempertimbangkan apakah setelah resepsi nanti mempunyai cukup uang untuk memenuhi kebutuhan hidup selanjutnya atau tidak. Selain itu, warga Desa $X$ memiliki kecenderungan untuk tidak mau kalah bersaing dengan tetangganya dalam hal kepemilikan materi. Sebagai contoh, jika ada tetangga yang membeli motor, maka ia harus membeli motor pula.

Kebiasaan Berutang. Berutang sudah menjadi kebiasaan hidup sebagian besar warga Desa X. Mereka berutang kepada saudara, warung, bank harian hingga rentenir. Berutang kepada saudara atau tetangga biasanya dilakukan untuk dapat memenuhi kebutuhan sehari-hari saat laut sedang mengalami musim paceklik. Berutang tidak hanya dilakukan untuk memenuhi kebutuhan hidup saja, melainkan juga memenuhi kebutuhan konsumtif. Salah satu kebutuhan konsumtif yang dapat diatasi dengan berutang adalah jajan anak, membeli sejumlah barang seperti pakaian bermerek terkenal, furnitur, peralatan elektronik, atau hajatan.

TKW di Desa X. Profesi TKW mulai dikenal oleh warga Desa $\mathrm{X}$ pada awal tahun 1990-an. Ketika itu negara yang menjadi tujuan hanya Arab Saudi dengan jenis pekerjaan umumnya sebagai pembantu rumah tangga. Rata-rata peminatnya ketika itu adalah warga desa yang tidak dapat melanjutkan pendidikan ke tingkat Sekolah Menengah Pertama, yang masih berusia belasan tahun. Di Desa $\mathrm{X}$, pekerjaan sebagai buruh migran lebih banyak dilakukan oleh perempuan. Menurut seorang narasumber, terdapat sejumlah alasan yang membuat TKW di Desa X didominasi oleh perempuan. Alasan pertama adalah karena profesi pembantu rumah tangga yang dijalani perempuan merupakan profesi yang sangat dibutuhkan di luar negeri, khususnya Timur Tengah, bila dibandingkan profesi lain yang dijalani pria (misalnya pengemudi). Permintaan yang tinggi dari negara tujuan tersebut membuat TKW dengan cepat dapat segera diberangkatkan oleh PJTKI untuk bekerja. Tingginya penghasilan yang diterima dan mudahnya persyaratan yang harus dipenuhi (hanya menyertakan KTP, bukan ijazah) juga menjadi faktor yang membuat mereka lebih memilih bekerja sebagai pembantu rumah tangga di luar negeri daripada buruh pabrik di dalam negeri. Alasan berikutnya adalah dewasa ini TKW yang ingin bekerja ke luar 
negeri tidak perlu membayar uang kepada sponsor sebagai salah satu persyaratan seperti sebelumnya. Bahkan, saat ini TKW mendapat uang saku dari sponsor. Hal ini berbeda dengan buruh migran pria yang harus menyetor uang hingga tujuh juta rupiah pada sponsor untuk dapat bekerja ke luar negeri. Alasan selanjutnya mengapa profesi buruh migran Desa $\mathrm{X}$ didominasi dan lebih diminati oleh perempuan adalah karena profesi nelayan sudah mendarah daging dalam diri sebagian besar pria di Desa X. Mereka merasa tidak memiliki keahlian lain yang dibutuhkan pasar kerja di luar negeri sehingga tetap memilih bekerja di dalam negeri sebagai nelayan.

Motivasi utama para perempuan di Desa X ini menjadi TKW adalah untuk memenuhi kebutuhan keluarga. Ketika masih lajang, misi mereka adalah membantu perekonomian keluarga (khususnya orangtua). Setelah menikah, kepergian mereka ditujukan untuk membantu suami mencari nafkah. Nelayan dan buruh 'serabutan' merupakan profesi dari sebagian besar suami para TKW ini.

Sejumlah narasumber mengemukakan, seiring dengan keberhasilan para TKW membawa perbaikan ekonomi bagi keluarganya, profesi TKW menjadi populer dan semakin menarik minat warga Desa $X$ lainnya untuk mengikuti kesuksesan temantemannya. TKW dianggap sebagai jalan pintas menuju kemakmuran. Jika hanya mengandalkan dari hasil melaut, warga Desa X merasa tidak akan bisa memperoleh penghasilan yang besar, yang dapat digunakan untuk membeli rumah atau emas. Menurut penuturan sejumlah narasumber, keberhasilan teman atau tetangga yang lebih dulu menjadi TKW juga memotivasi warga untuk bekerja di luar negeri, sehingga semakin menambah kepopuleran jenis pekerjaan ini.

Meski pada saat masih aktif menjadi TKW mereka mampu membeli rumah, kendaraan bermotor, atau menyelenggarakan pesta, namun setelah kembali ke desanya dan selama beberapa lama tidak bekerja, tetap saja ada TKW yang kesulitan dalam memenuhi kebutuhan keluarganya. Ini terlihat dari bagaimana mereka harus berutang untuk memenuhi kebutuhan hidup sehari-hari atau menjual harta yang dimilikinya.

Meski terjadi pergeseran peran suami dan istri pada warga Desa $X$, dimana saat ini istri tidak semata-mata mengurus domestik namun juga sebagai pencari nafkah, namun paradigma yang dianut TKW tentang bagaimana seharusnya peran suami dan istri dalam pernikahan masih bersifat tradisional. Para TKW masih meyakini bahwa tugas mencari nafkah masih menjadi bagian dari tugas suami, sementara pekerjaan domestik seperti mengurus rumah, memasak, atau mencuci pakaian merupakan tugas istri. Selain itu, meski pada saat-saat tertentu menjadi tulang punggung keluarga, mereka masih merasa perlu untuk tetap melayani dan taat pada suami, (dengan catatan: selama suami berperilaku baik).

Pernikahan Dini dan Perceraian. Menurut Kepala Kantor Urusan Agama (KUA) Kecamatan Juntinyuat, yang membawahi Desa X (wawancara, 7 Oktober 2013), berdasarkan Undang-Undang Pernikahan tahun 1974, usia minimal bagi seorang gadis untuk menikah adalah 16 tahun, sementara untuk jejaka harus sudah berusia 19 tahun. Pada kenyataannya, batasan usia ini tidak selalu dapat dipenuhi oleh calon pengantin, termasuk calon pengantin di Desa X. Tidak sedikit calon pengantin yang mengajukan permohonan menikah dengan tidak memenuhi persyaratan usia pernikahan yang ditetapkan. Menghadapi hal ini petugas KUA terpaksa mengabulkan permohonan tersebut karena biasanya calon pengantin telah hamil sebelum menikah dan pernikahan dianggap sebagai cara untuk menutupi aib. Hal lain yang membuat petugas KUA terpaksa mengizinkan calon pengantin yang belum cukup usia untuk menikah adalah karena desakan keluarga calon pengantin yang mengkhawatirkan terjadinya zina jika calon pengantin tidak segera dinikahkan. Mengingat zina dianggap mencederai 
norma-norma masyarakat sehingga harus dihindari, petugas KUA tidak memiliki pilihan lain selain menikahkan pasangan yang sebenarnya masih belum memenuhi persyaratan usia tersebut. Dalam kasus yang demikian, dimana calon pengantin belum cukup umur untuk menikah maka petugas KUA akan memberikan surat izin menikah dan harus ditandatangani oleh orangtua calon pengantin.

Aparat pemerintah Indramayu mengemukakan tingginya angka perceraian di Indramayu memiliki korelasi dengan mudanya usia saat menikah. Seorang staf Pengadilan Agama Indramayu mengemukakan mudanya usia saat melangsungkan pernikahan turut berperan dalam mudahnya keputusan untuk mengakhiri pernikahan. Ia menuturkan, usia yang terlalu muda saat menikah dinilai membuat individu belum siap secara mental maupun materil untuk menjalani kehidupan pernikahan.

\section{Gambaran Pernikahan TKW}

Istri Bekerja adalah Hal yang Biasa. Semakin populernya profesi sebagai TKW di Desa X, membuat banyak perempuan Desa $\mathrm{X}$ menjalaninya. Tidak sedikit dari mereka yang telah menikah dan karenanya harus meninggalkan suami dan anak-anak di rumah untuk bekerja sebagai TKW di luar negeri. Kepergian istri ke luar negeri ini dapat terjadi karena dorongan suami ataupun juga karena inisiatif istri sendiri, yang ingin memenuhi keinginan materi tertentu. Keinginan istri untuk bekerja di luar negeri bukan hanya karena demi mengejar ambisi ekonomi tertentu, namun juga karena menyadari bahwa penghasilan suami tidak mencukupi.

Bekerjanya istri ke luar negeri membuat peran istri yang tadinya lebih banyak mengurus rumah tangga bergeser menjadi peran sebagai pencari nafkah. Beralihnya peran istri sebagai pencari nafkah ini tidak menjadi masalah besar bagi para istri itu sendiri selama suami tetap menjalankan perannya sebagai pencari nafkah dengan tekun dan rajin bekerja. Konflik timbul manakala suami dianggap malas bekerja, sementara istri telah bekerja keras. Adapun bagi suami, keterlibatan istri sebagai pencari nafkah dengan menjadi TKW ini dianggap sebagai hal yang biasa. Suami tidak merasa malu karena menganggap fenomena tersebut sebagai sesuatu yang sudah banyak terjadi di desanya. Pada kasus-kasus tertentu, justru ketika istri tidak mampu mencari peluang untuk mencari nafkah, hal tersebut akan menimbulkan konflik dengan suami, karena bagi suami, istri bukan saja dituntut menjalani peran mengurus rumah saja, namun juga sebagai pencari nafkah meski hasilnya tidak banyak.

Fenomen 'Duda Arab' dan Potensi Konflik pada Pernikahan TKW. Dalam penelitiannya mengenai TKW Indramayu, Rosadi (2010) melaporkan fenomena yang nampak nyata dari kepergian para istri menjadi TKW ini adalah adanya sebutan Duda Arab yang diperuntukkan bagi kaum suami yang ditinggal istrinya bermigrasi (mayoritas ke Timur Tengah). Sementara itu, bila yang bekerja ke luar negeri adalah suami, sementara sang istri tetap berada di desa, maka sebutan bagi istri ini adalah Rangda (Janda) Malaysia. Disebut Duda Arab adalah karena mayoritas negara tujuan para istri ini adalah Arab Saudi dan mereka harus meninggalkan suaminya sementara waktu. Adapun sebutan Rangda Malaysia timbul karena bila yang berangkat adalah suami, mayoritas tujuan negara mereka adalah Malaysia. Menurut Rosadi (2010) sebutan tersebut merupakan sesuatu yang lazim dan tidak memiliki konotasi negatif atau positif.

Di Desa X, aktivitas para Duda Arab selama ditinggal istrinya bekerja di luar negeri ini adalah beragam. Ada Duda Arab yang mencari nafkah di sekitar tempat tinggal (biasanya sebagai nelayan atau buruh di tempat penjemuran ikan dan tempat pelelangan ikan), sehingga tidak hanya mengandalkan penghasilan kiriman istri. Meski demikian, ada pula Duda Arab yang tidak bekerja dan mengisi waktu dengan mengobrol di warung seharian, main perempuan, menghabiskan uang kiriman istri untuk kesenangan pribadi, 
berjudi, mabuk, atau tidak mengasuh anakanaknya dengan benar. Perilaku Duda Arab yang negatif ini sering menimbulkan konflik dengan istri. Konflik dapat terjadi setelah istri pulang kembali ke Indonesia dan mendapati bahwa ternyata perilaku suaminya tidak sesuai dengan apa yang diharapkan. Selain itu, konflik bisa pula terjadi saat istri masih berada di luar negeri. Tidak jarang para istri terkejut dengan perilaku suaminya karena sebelumnya merasa suami tidak akan berperilaku negatif selama ditinggal istri bekerja di luar negeri. Konflik ini pada akhirnya membuat istri ingin mengakhiri pernikahan.

Peran Orang Tua dalam Mengakhiri Komitmen Pernikahan. Keluarga besar tampaknya turut memengaruhi keberlangsungan pernikahan di Desa X, khususnya pada mereka yang pasangannya bekerja ke luar negeri. Sebagai contoh, pihak keluarga istri memiliki peran dalam mengawasi perilaku para Duda Arab. Biasanya mereka melaporkan perbuatan Duda Arab yang dianggap negatif ini kepada anaknya (istri Duda Arab tersebut) yang masih berada di luar negeri. Sebaliknya, jika menantunya berperilaku benar, maka keluarga tidak melakukan hal yang demikian.

Pengaruh keluarga dalam keberlangsungan pernikahan TKW juga muncul dalam bentuk penghasut atau penebar kabar mengenai keburukan suami atau istri yang hidup terpisah tersebut. Perilaku keluarga yang seperti ini umumnya dilakukan dengan tujuan menguasai uang kiriman dari anaknya, tanpa mau berbagi dengan menantu. Tidak menutup kemungkinan ada orangtua yang masih ingin meminta materi dari anak perempuannya yang telah berkeluarga. Orangtua yang demikian, dalam istilah warga Desa $\mathrm{X}$, disebut 'wong tuo masih kepengen pakeane anak, yang dapat mendorong timbulnya perceraian suami istri. Hasutan keluarga dapat menimbulkan berbagai macam respon pada TKW. Salah satunya adalah kebingungan. Kebingungan ini biasanya terjadi ketika mereka memercayai suami sebagai pribadi yang baik, namun sekaligus merasa tidak mungkin keluarga terdekat tega menghancurkan pernikahannya dengan menebarkan kabar yang tidak benar. Pada sebagian orang, kebingungan ini kemudian memicunya untuk mencari tahu mengenai apa yang sebenarnya terjadi sebelum mereka memutuskan mengambil tindakan tertentu (misalnya bercerai). Mereka menganggap langsung memercayai hasutan keluarga (atau orang lain) begitu saja hanya akan merugikan diri sendiri. Hasutan keluarga tentang perilaku suami tidak hanya dikemukakan oleh keluarga besar istri kepada istri, namun juga dapat terjadi sebaliknya, yakni keluarga besar suami yang mengemukakan hasutan tersebut kepada suami mengenai perilaku istrinya selama ditinggal suami bekerja ke luar negeri.

Para TKW ada yang memilih untuk tidak begitu saja memercayai berita yang diterima, meskipun masih ada pula TKW yang merespon hasutan keluarga dengan langsung memercayai begitu saja tanpa membuktikan dahulu kebenarannya. Mereka yang menggunakan cara demikian akan langsung memutuskan untuk mengakhiri komitmen pernikahan, walaupun masih berada di luar negeri. Selain menghasut dengan menebarkan kabar yang belum tentu benar, ada pula keluarga yang mendorong pasangan suami istri yang berselisih untuk segera mengakhiri komitmen pernikahannya, daripada memberi saran atau solusi bagi pertikaian yang terjadi agar tidak berujung pada perceraian. Adakalanya berakhirnya komitmen pernikahan terjadi justru karena ada dorongan atau permintaan dari orangtua. Bahkan, saat istri atau suami masih berada di luar negeri, perceraian tersebut sudah terjadi. Adakalanya pula suami istri masih ingin bersatu dan menerima keadaan masing-masing, namun justru orangtuanya yang tidak dapat menerima dan menyarankan perpisahan. Ada pula anak yang terpaksa menuruti keinginan orangtuanya untuk mengakhiri komitmen pernikahannya daripada mengikuti suami karena menganggap orang tua sebagai figur yang tidak tergantikan. 
Mereka beranggapan lebih mudah mencari pengganti suami dibandingkan mencari pengganti orangtua. Meski demikian, ada pula anak yang tidak menuruti permintaan orangtuanya untuk bercerai karena tidak ingin orangtuanya mencampuri urusan rumah tangganya.

Peran Perangkat Desa dalam Pernikahan dan Perceraian TKW. Perangkat desa tidak dapat berbuat banyak untuk mencegah berakhirnya komitmen pernikahan pada pasangan yang bertikai. Adanya anggapan bahwa masalah rumah tangga merupakan masalah keluarga membuat upaya yang dilakukan perangkat desa untuk meningkatkan kualitas pernikahan warga dan menurunkan angka perceraian selama ini bukan bersifat formal. Perangkat desa merupakan pintu terakhir yang didatangi oleh pasangan yang bertikai. Menurut mereka, ketika suami dan istri pada akhirnya mendatangi perangkat desa untuk berkonsultasi, itu artinya masalah tersebut sudah tidak dapat diselesaikan oleh pihak keluarga, dimana keluarga merasa tidak berhasil menemukan solusi yang baik. Menghadapi pasangan yang datang berkonsultasi, perangkat desa hanya bisa memberi pandangan atau nasehat bagi pasangan yang bertikai tersebut dan menyerahkan segala keputusan akhir pada mereka berdua. Seperti yang dituturkan oleh kuwu atau kepala desa bahwa mereka tidak dapat berbuat banyak dalam mengatasi konflik atau pertikaian pasangan suami istri, perangkat desa hanya bisa melakukan upaya preventif terkait hal tersebut. Melalui khotbah nikah yang disampaikan pada saat akad nikah, amil atau lebe mengingatkan mengenai hak dan kewajiban suami istri. Dengan demikian diharapkan mereka dapat lebih memahami posisinya masing-masing dalam rumah tangga dan bertenggang rasa dengan pasangannya, sehingga dengan demikian diharapkan tidak melakukan halhal yang dapat melemahkan komitmen pernikahan. Upaya preventif lain yang dilakukan dengan menetapkan aturan; mengharuskan istri meminta izin kepada suami jika hendak bekerja sebagai TKW.
Kebijakan ini dibuat karena tidak sedikit konflik dalam rumah tangga terjadi akibat istri bekerja sebagai TKW.

TKW dan Konflik Pernikahan. Konflik dalam pernikahan TKW pada umumnya terdiri dari tiga topik, yakni perselingkuhan, masalah ekonomi (peggunaan penghasilan istri oleh suami dengan tidak semestinya), serta konflik antara mertua dengan menantu. Konflik tersebut biasanya terjadi ketika TKW sedang bekerja di luar negeri atau sesaat setelah kembali dari luar negeri. Terkait berbagai konflik yang terjadi, upaya TKW dalam memelihara relasi pernikahan ditentukan oleh penilaian terhadap kesediaan suami dalam menjalankan peran sebagai kepala rumah tangga, responsivitas suami terhadap kebutuhan istri, serta perilaku tertentu yang dilakukan suami. Penilaian yang positif akan mendorong TKW untuk melakukan tindakan pemeliharaan relasi seperti memaafkan kesalahan suami, menerima keadaan, sabar atas keadaan, mensyukuri keadaan, dan mengembangkan sikap percaya pada suami pada saat dihadapkan dengan situasi yang ambigu. Penilaian yang positif terhadap pengalaman sebelumnya dengan suami pada akhirnya akan mengarahkan TKW untuk mempertahankan komitmen pernikahannya meski timbul konflik rumah tangga. Sebaliknya, penilaian yang negatif terhadap suami akan mendorong mereka untuk mengakhiri pernikahan.

\section{Diskusi}

Pembahasan hasil penelitian ini akan ditinjau dari perspektif teori Bioekologi (Bronfenbrenner, 2005). Teori Bioekologi menyatakan bahwa perkembangan individu merupakan hasil dari interaksi antara individu tersebut dengan context lingkungan yang mengelilinginya, baik itu lingkungan makrosistem, eksosistem, mesosistem, dan mikrosistem (Bronfenbrenner, 2005).

Makrosistem - Eksosistem terkait Migrasi. Dalam context makrosistem, terdapat sejumlah kondisi sosiokultural setempat yang mendorong para istri untuk 
menjadi TKW, yang mana keberangkatan mereka ke luar negeri ini memicu terjadinya sejumlah konflik dengan lingkungan terdekatnya, termasuk pasangan. Di dalam makrosistem, peneliti melihat ada keterkaitan antara migrasi yang dilakukan oleh TKW dengan situasi yang berpotensi memengaruhi komitmen pernikahan. Keterkaitan ini tercermin pula pada migrasi 'memaksa' mereka untuk menjalani pernikahan dengan tinggal terpisah dari pasangan, yang mana situasi ini merupakan pemicu timbulnya permasalahan dalam pernikahan. Context makrosistem memengaruhi komitmen pernikahan pada partisipan secara tidak langsung, yakni melalui sejumlah kondisi yang mendorong mereka untuk bekerja sebagai TKW.

Teori Bioekologi menyatakan, yang termasuk kondisi makrosistem adalah budaya atau struktur sosial (seperti kelas, suku, wilayah, sumber daya, gaya hidup, struktur kesempatan) yang terdapat pada lingkungan dimana individu tinggal (Bronfenbrenner, 2005). Kondisi makrosistem yakni berupa kesulitan, terbatasnya sumber daya dan terbatasnya kesempatan struktural pada lingkungan setempat mendorong para TKW memilih untuk meninggalkan desanya dan kemudian bekerja di luar negeri.

Kondisi makrosistem lain yang patut diduga melatarbelakangi TKW ini bermigrasi adalah gaya hidup masyarakat setempat yang konsumtif, kebiasaan berutang, ingin cepat kaya, serta tidak mau kalah bersaing secara materi dengan orang lain. Terkait dengan hal ini, tampaknya gaya hidup yang demikian bisa jadi telah menjadi karakteristik khas dari masyarakat Indramayu secara umum atau masyarakat nelayan secara khusus (Kasim, 2010; Soedijar, 2004). Dari hasil penelitian yang dilakukannya di Indramayu, Soedijar (2004) menganalisis bahwa yang dianggap sebagai simbol kesuksesan bagi masyarakat golongan sosial ekonomi bawah dan berpendidikan rendah adalah kepemilikan materi tertentu, seperti rumah dengan segala perabotannya, peralatan elektronik, pakaian bermerek, atau kendaraan bermotor, dan bukan keberhasilan di bidang pendidikan. Hasil penelitian Soedijar (2004) tersebut tidak menutup kemungkinan pula diyakini pula oleh masyarakat Desa $X$, sehingga menjadikan profesi TKW sebagai cara yang relatif mudah untuk memperoleh kepemilikan materi tertentu, yang dianggap sebagai simbol kesuksesannya. Menilik kesuksesan orang-orang di sekitarnya, profesi TKW kemudian dianggap sebagai sumber penghasilan baru yang lebih menjanjikan daripada melaut. Terpampangnya hasil kerja TKW secara nyata di penjuru desa, menjadikan profesi ini dianggap memberikan suatu kepastian, yakni 'setiap kali berangkat akan mendapatkan uang', sama halnya anggapan bahwa 'musim panen terjadi setiap kali melaut' yang dianut oleh para nelayan (Kasim, 2010).

Sementara itu, hal lain yang mendorong para istri ini untuk menjadi TKW adalah adanya kebijakan yang dikeluarkan oleh pihak terkait yang memudahkan prosedur keberangkatan TKW. Teori Bioekologi menyebutkan kebijakan yang dibuat organisasi/ lembaga di lingkungan individu berada dapat dikategorikan sebagai bagian dari eksosistem individu (Bronfenbrenner \& Morris, 2006). Dalam hasil penelitian ini, kebijakan tersebut dikeluarkan oleh PJTKI yang membebaskan biaya keberangkatan bagi perempuan yang hendak menjadi TKW, yang mana hal ini tidak berlaku bagi pria. Berbeda dengan perempuan, pria dibebankan biaya hingga jutaan rupiah untuk dapat bekerja di luar negeri. Dalam lingkup yang lebih luas, pemerintah Indramayu juga memberi dukungan yang besar terhadap warganya yang ingin menjadi TKW. Hasil penelitian Rosadi (2010) menyebutkan dukungan yang diberikan pemerintah tersebut berupa kemudahan dalam hal pengurusan dokumen perizinan, bahkan pemerintah memberikan uang sebesar satu juta rupiah sebagai modal awal kepada setiap calon TKW guna membantu mereka mengurus syarat-syarat yang diperlukan. 
Dukungan pemerintah ini kemungkinan timbul setelah melihat kenyataan bahwa remitan yang diperoleh warga Indramayu dari hasil pekerjaannya sebagai TKW merupakan yang tertinggi di Indonesia, yakni bisa mencapai 20 milyar rupiah perbulan (Rosadi, 2010). Sayangnya, tingginya remitan tersebut tidak diiringi oleh peningkatan kualitas masyarakat setempat. Rosadi (2007) mencatat, Indeks Pembangunan Manusia (IPM) masyarakat Z (kecamatan dimana Desa $\mathrm{X}$ berada) masih di bawah target yang diharapkan, yakni hanya sebesar 65.95 dari target 68.04 pada tahun 2007. Rosadi melihat angka tersebut sebagai ciri bahwa $\mathrm{Z}$ masih menghadapi masalah yang cukup serius dalam bidang pendidikan, kesehatan, atau ekonomi. Kurangnya kualitas sumber daya manusia inilah yang membuat mereka sulit mendapatkan pekerjaan dengan penghasilan memadai di dalam negeri sehingga menjadi faktor pendorong lainnya bagi warga setempat untuk menjadi TKW.

Context makrosistem lainnya yang turut mendorong terjadinya migrasi para TKW ini adalah pergeseran nilai-nilai masyarakat setempat tentang peran pencari nafkah. Bekerjanya para istri ke luar negeri menjadikan peran pencari nafkah utama dalam keluarga tidak lagi bertumpu pada suami. Pergeseran peran ini sudah menjadi hal yang dianggap biasa oleh masyarakat setempat yang mulanya, sama seperti budaya masyarakat nelayan lainnya, memosisikan istri sebagai pengelola rumah tangga (Kasim, 2010). Pergeseran peran pencari nafkah dari suami kepada istri menjadi lebih mudah diterima oleh masyarakat tatkala ada keadaan yang memaksanya demikian. Sebagai contoh, hasil penelitian Haryono dan Suciarto (2010) pada masyarakat Yogyakarta menunjukkan bahwa para partisipan penelitian menganggap perempuan (istri) dimungkinkan untuk mencari nafkah ketika kondisi ekonomi keluarga tidak mencukupi untuk pemenuhan kebutuhan sehari-hari. Pada masyarakat Desa X, terdapat kondisi struktural dan sosial yang membuat kesempatan suami dalam memeroleh penghasilan yang memadai menjadi lebih terbatas dibandingkan istri, yang pada akhirnya membuat mereka menjadi lebih dapat menerima pergeseran peran yang terjadi. Kondisi-kondisi tersebut antara lain, rendahnya pendidikan, kebijakan Perusahaan Jasa Tenaga Kerja Indonesia (PJTKI) setempat yang dianggap menyulitkan para suami ini untuk menjadi TKW, atau profesi nelayan yang sudah mengakar kuat sehingga membuat mereka enggan beralih ke profesi lain saat musim paceklik tiba.

Eksosistem. Pengaruh eksosistem dalam pernikahan para TKW terlihat dari belum maksimalnya usaha aparat yang berwenang, seperti perangkat desa, untuk mendamaikan pasangan yang bertikai karena adanya anggapan bahwa masalah rumah tangga merupakan masalah keluarga. Peran perangkat desa merupakan bagian dari eksosistem. Eksosistem merupakan struktur masyarakat dimana individu berada, yang mana individu tidak secara langsung berpartisipasi di sana, namun hal tersebut tetap dapat memengaruhi perkembangan individu (Bronfenbrenner, 2005). Belum maksimalnya usaha yang dilakukan oleh perangkat desa tersebut terjadi karena adanya anggapan yang dianut masyarakat setempat bahwa konflik dalam pernikahan adalah persoalan domestik yang harus diselesaikan tanpa melibatkan pihak luar, dalam hal ini perangkat desa. Adanya anggapan tersebut ternyata bukan hanya menyebabkan belum optimalnya peran perangkat desa di Desa $X$ saja, namun juga peran lembaga lainnya (seperti Badan Penasihat Pembinaan dan Pelestarian Perkawinan, BP4) di wilayah lain di Indramayu. Sebagai contoh, hasil penelitian Nazarudin (1998) mendapati bahwa fungsi BP4, yang berada di bawah KUA, ternyata masih kurang dikenal oleh masyarakat. Hal ini terlihat dari jumlah keluarga yang berkonsultasi, yang hanya sebanyak 52 kepala keluarga (KK) dari $18.481 \mathrm{KK}$ yang ada. Menurut kepala KUA setempat, masih minimnya jumlah keluarga yang berkonsultasi ke BP4 disebabkan oleh jarangnya 
masyarakat mengadukan masalah keluarga ke BP4 karena menganggap masalah keluarga tidak boleh diketahui oleh orang lain dan hanya mereka sendiri yang harus menyelesaikan. Selain itu, kurangnya pemanfaatan BP4 sebagai lembaga konsultasi pra-cerai dipengaruhi pula oleh adanya kebiasaan menikah siri (tidak diketahui oleh KUA) pada warga setempat. Adanya pernikahan siri tersebut membuat mereka menganggap ketika mengalami masalah dalam rumah tangga, maka solusinya adalah melakukan perceraian secara siri (di bawah tangan) pula dan tidak perlu diketahui oleh pihak BP4 atau KUA. Padahal, seharusnya ketika hendak mengakhiri pernikahan, pasangan diharapkan berkonsultasi dahulu ke lembaga yang berwenang tersebut.

Mesosistem - Konflik antara Suami dengan Keluarga Besar Istri. Mesosistem merupakan context dimana interaksi antara dua atau lebih mikrosistem individu terjadi (Bronfenbrenner, 2005). Context mesosistem yang berpotensi memengaruhi komitmen pernikahan para TKW di Desa X adalah konflik yang terjadi antara suami dengan keluarga besar istri. Baik suami maupun keluarga besar dapat dikategorikan sebagai mikrosistem yang mengelilingi istri, yang berinteraksi dalam context mesosistem TKW tersebut.

Hasil penelitian ini menunjukkan, konflik antara suami dengan keluarga besar istri dapat terjadi karena adanya keinginan keluarga besar istri untuk menguasai penghasilan yang diperoleh istri. Peneliti berpendapat, adanya keinginan menguasai penghasilan tersebut dimungkinkan terjadi karena orang tua telah terbiasa menerima penghasilan dalam jumlah besar dari anak perempuannya sejak masih lajang, yang mana pernikahan membuat penghasilan tersebut harus terbagi kepada pihak lain, yakni menantunya. Jika menilik bagaimana seorang anak diposisikan dalam keluarga, maka menjadi dapat dimengerti ketika para orangtua di desa tersebut menganggap wajar perilakunya yang menginginkan penghasilan anak tersebut. Terkait dengan hal tersebut, dalam masyarakat Indonesia sendiri, anak memang diposisikan sebagai penyokong ekonomi keluarga (Koentjaraningrat, 1994; Albert dkk., 2005). Harapan ini bahkan telah disampaikan oleh orangtua sejak anak masih kecil. Hal ini terlihat dalam penelitian yang dilakukan Rosadi (2010) di Kecamatan Juntinyuat, Indramayu, dimana salah seorang narasumber menuturkan bahwa orangtua di wilayah setempat, saat menimang anaknya dengan nyanyian, seringkali menyampaikan harapan agar kelak ketika dewasa anak dapat membantu perekonomian keluarga dengan bekerja di Arab Saudi, meski hanya menjadi pembantu rumah tangga. Secara khusus, dibandingkan dengan anak laki-laki, anak perempuan dianggap memiliki nilai yang lebih berharga secara ekonomi oleh masyarakat Indramayu karena lebih mudah mendapatkan pekerjaan yang dianggap berpenghasilan besar (Soedijar, 2004; Darmawan, 2010).

Mikrosistem dan Mesosistem. Dalam context mikrosistem dan mesosistem, migrasi yang dilakukan istri untuk bekerja menimbulkan konflik dengan lingkungan mikrosistemnya (suami) maupun konflik pada lingkungan mesosistemnya (antara suami dengan keluarga besar) yang pada akhirnya memengaruhi komitmen pernikahan. Konflik ini semakin berpotensi merusak komitmen pernikahan ketika didukung oleh faktor lain, yakni keluarga (mikrosistem) yang justru mendukung terjadinya perceraian.

Mikrosistem - Keluarga Besar (Orangtua). Mikrosistem merupakan context dimana interaksi antara individu dengan lingkungan terdekatnya terjadi (Bronfenbrenner, 2005). Salah satu mikrosistem para TKW ini adalah keluarga besar atau orangtuanya. Temuan penelitian ini menunjukkan adanya peran orangtua di Desa $\mathrm{X}$ dalam menghasut atau mendorong anaknya agar mengakhiri komitmen pernikahan. Terkait dengan hal ini, pernikahan di Indonesia memang cenderung masih dipengaruhi oleh keputusan-keputusan yang 
dibuat orangtua. Pengaruh ini sudah dirasakan, bahkan, sejak individu baru memilih pasangan hidupnya, dengan cara mencarikan mereka pasangan (Jones, Asari, \& Djuartika, 1994; Situmorang, 2005) atau memberi mereka pengarahan agar mencari pasangan dengan kriteria tertentu (SmithHefner, 2005). Jika umumnya campur tangan orangtua dalam pernikahan terjadi pada mereka yang belum mandiri secara ekonomi (Hakim, 2003), maka di Desa X, tindakan campur tangan orangtua yang meminta anaknya bercerai justru terjadi karena mereka ingin ikut menikmati dan menguasai keberhasilan ekonomi anaknya.

Sejumlah penelitian menunjukkan bahwa keluarga besar memiliki peran yang dapat bertolak bagi kelangsungan pernikahan individu. Di satu sisi, keluarga dapat mendorong individu tetap mempertahankan pernikahannya, seperti yang terlihat dari hasil penelitian Cox dkk. (1997) yang menunjukkan bahwa semakin besar dukungan yang didapat dari keluarga membuat kecenderungan individu untuk mempertahankan relasi pernikahan semakin meningkat. Sebaliknya, di sisi lain keluarga dapat mendorong individu untuk mengakhiri pernikahannya (Jones, Asari, \& Djuartika, 1994). Besarnya pengaruh keluarga terhadap keberlangsungan pernikahan individu terjadi karena adanya peran norma subyektif yang dimiliki individu, yang bersumber dari keluarga itu sendiri (Ajzen, 1991), dimana pada hampir semua kebudayaan lokal di Indonesia, keluarga dianggap sebagai lembaga utama yang sangat dijunjung tinggi (Suhartini, 2013). Menurut Ajzen (1991), norma subyektif merupakan penentu intensi individu untuk berperilaku, yakni ketika individu merasa orang yang relevan dalam hidupnya (di Indonesia, umumnya keluarga) lebih menyukai ketika ia mempertahankan pernikahannya daripada mengakhirinya (Johnson dkk., 1999; Levinger, 1976), maka intensinya untuk mempertahankan pernikahannya semakin besar.
Mikrosistem - Fenomena Perilaku Negatif 'Duda Arab'. Teori Bioekologi menyatakan bahwa pada umumnya individu dapat berinteraksi dengan lebih dari mikrosistem yang ada di sekitarnya (Bronfenbrenner, 2005). Selain berinteraksi dengan keluarga, pada level mikrosistem, para TKW di Desa X juga berinteraksi dengan suaminya. Hasil penelitian ini menunjukkan bahwa migrasi istri ke luar negeri berpotensi menjadikan suami sebagai Duda Arab yang berperilaku negatif, seperti mabuk, main perempuan, berjudi, tidak mengasuh anak dengan benar, atau menghambur-hamburkan penghasilan yang dikirim oleh istri. Fenomena ini seringkali memicu konflik pada mereka karena dianggap sebagai bentuk kegagalan suami dalam menjalankan peran yang diamanahkan (misalnya mengelola uang, mengasuh anak) kepadanya selama ditinggal istri ke luar negeri (Hakim, 2003).

Pada kenyataannya perilaku negatif yang dilakukan para 'Duda Arab' di Desa X juga terjadi pada TKW di wilayah lainnya seperti baik di Indramayu (misalnya kecamatan Bongas, hasil penelitian Wazdi, 2006) atau di luar Indramayu (misalnya Tulung Agung, hasil penelitian Hakim, 2003). Dengan demikian, dapat dikatakan bahwa gejala tersebut merupakan 'ongkos sosial' bagi pernikahan, yang harus dibayar dari bermigrasinya istri ke luar negeri. Selanjutnya yang kemudian harus diwaspadai adalah lemahnya kontrol sosial sehingga membuat seorang suami menganggap wajar melakukan hal tersebut karena hal tersebut telah banyak dilakukan oleh orang-orang lain di sekitarnya.

\section{Proximal Process antara TKW} dengan Suami. Hasil penelitian ini menunjukkan interaksi antara partisipan dengan context mikrosistem atau lingkungan terdekatnya, dalam hal ini suami yang memberikan pengaruh secara langsung dan lebih kuat pada komitmen pernikahan mereka. Teori Bioekologi menjelaskan bahwa inti atau penentu utama perkembangan manusia adalah interaksi yang bersifat terus-menerus dan timbal balik 
antara individu dengan mikrosistemnya (lingkungan terdekat). Interaksi tersebut dinamakan proximal process. Dengan demikian, faktor yang paling berpengaruh bagi komitmen pernikahan individu adalah proximal process yang terjadi sejak awal pernikahan hingga saat ini antara partisipan dengan suaminya, selaku lingkungan terdekatnya tersebut, dan bukan hal lain yang berada dalam konteks lingkungan yang lebih jauh. Selain itu, mengingat salah satu karakteristik intimate relationship adalah adanya saling keterkaitan antara individu dengan pasangannya (Miller \& Perlman, 2008), maka perilaku apapun yang ditampilkan individu akan berpengaruh terhadap individu lain yang menjadi pasangannya (Berscheid, Snyder, \& Omoto, 2004). Penjelasan inilah yang melandasi mengapa interaksi partisipan dengan pasangan, selaku mikrosistemnya, lebih memengaruhi komitmen pernikahan daripada context lingkungan yang lebih luas (makrosistem). Sementara itu menurut teori Interdependensi, sejauhmana suatu relasi memberikan keuntungan (reward) menjadi acuan bagi individu untuk mempertahankan atau tidak mempertahankan relasinya (Rusbult, Arriaga, \& Agnew, 2003). Dalam hal ini, proximal process yang negatif akan mendorong individu untuk memersepsi adanya cost dalam relasi, sementara proximal process yang positif mendorong individu untuk memersepsi adanya reward dalam relasi. Adanya reward yang lebih besar daripada cost mendorong terbentuknya ketergantungan individu terhadap relasi yang dijalani (Rusbult, Arriaga, \& Agnew, 2003).

\section{Simpulan}

Secara ringkas, hasil penelitian menunjukkan dinamika kehidupan pernikahan, termasuk dinamika komitmen pernikahan, TKW asal Indramayu memiliki pertalian dengan interaksi antara individu tersebut dengan context lingkungan yang mengelilinginya, yakni lingkungan makrosistem, eksosistem, mesosistem, dan mikrosistem. Lingkungan makrosistem merupakan pre-determined bagi interaksi antara berbagai konteks lingkungan yang mengelilingi partisipan, yakni mikrosistem (interaksi partisipan dengan pasangan, keluarga, atau lingkungan sekitarnya), mesosistem (interaksi pasangan dengan keluarga partisipan). Lingkungan makrosistem dan eksosistem menciptakan situasi yang mendorong TKW bermigrasi untuk bekerja di luar negeri, yang pada akhirnya memicu konflik dalam pernikahan, baik konflik yang melibatkan mikrosistem (antara istri dengan suami; istri dengan keluarga besar) maupun mesosistem (antara suami dengan keluarga besar). Pasca konflik, keputusan TKW untuk mempertahankan atau mengakhiri komitmen pernikahan berkaitan dengan interaksinya dengan mikrosistemnya, dalam hal ini berbentuk proximal process antara TKW dengan suaminya.

\section{Saran}

Teori Bioekologi menekankan pentingnya faktor bioekologi dan faktor personal dalam perkembangan individu. Penelitian ini lebih menitikberatkan pada faktor bioekologi dan kurang mengetengahkan faktor personal sebagai hal yang mungkin berperan dalam pernikahan TKW. Dengan demikian, saran teoritis yang dapat diajukan untuk penelitian selanjutnya dengan topik serupa, dapat dilakukan dengan mengeksplorasi faktor-faktor personal tersebut.

Hasil penelitian ini menunjukkan adanya keterkaitan antara lingkungan makrosistem, eksosistem, mesosistem, maupun mikrosistem dengan relasi pernikahan TKW. Terkait dengan hal tersebut, saran praktis yang dapat diajukan adalah perlu dilibatkannya berbagai konteks lingkungan tersebut dalam merancang kebijakan terkait migrasi TKW, khususnya yang menyangkut aspek kehidupan keluarga. Selain itu, hasil penelitian ini menunjukkan adanya persoalan-persoalan dalam pernikahan yang dicetuskan oleh migrasi yang dilakukan istri. Terkait dengan hal tersebut, perlu dirumuskan suatu 
kebijakan yang berfokus pada penguatan relasi pernikahan sebelum, saat, dan setelah istri bermigrasi.

\section{Referensi}

Agnew, C. R., Van Lange, P. A. M., Rusbult, C. E., \& Langston, C. A. (1998). Cognitive interdependence: Commitment and the mental representation of close relationship. Journal of Personality and Social Psychology, 74, 939-954.

Ajzen, I. (1991). Attitudes, personality, and behavior. Berkshire, England: Open University Press, McGraw-Hill Education.

Albert, I., Trommsdorff, G., Mayer, B. Schwarz, B. (2005). Value of children in urban and rural Indonesia: Sociodemographic indicators, cultural aspects, and empirical findings. In Gisela Trommdorff and Bernhard Nauck (Eds.), The value of children in cross-cultural perspective: Case studies from eight society. (pp.171-207). Lengerich: Pabst Science.

Allgood, S. M., Harris, S., Skokgrand, L., \& Lee, T. R. (2009). Marital commitment and religiosity in a religiously homogenous population. Marriage and Family Review, 45, 52-67.

Anisa, R., Ramani, A., Prasetyowati, I. (2015). Intensi orang tua dalam pengambilan keputusan untuk menikahkan anak perempuan di bawah usia 20 tahun di Kecamatan Pakem, Kabupaten Bondowoso. E-Jurnal Pustaka Kesehatan, 3(3), 500-506.

Arriaga, X. B., \& Agnew, C. R. (2001). Being committed: Affective, cognitive and conative components of relationship commitment. PSPB, 27(9), 1190-1203.

Birnie, C., McClure, M. Z., Lydon, Z. E., \& Holmberg, D. (2009). Attachment avoidance and commitment aversion: A script for relationship failure. Personal Relationship, 16, 79-97.

Bronfenbrenner, U. (2005). Making human being human: Bioecological perspective on human development. California: Sage Publications, Inc.

Bronfenbrenner, U., \& Morris, P. A. (2006). The bioecological model of human development. In Damon, William, \& R.M. Lerner, Handbook of child psychology, volume one theoretical models of human development (pp.793-829). Canada: John Wiley \& Sons, Inc.

Cox, C. L., Wexler, M. O., Rusbult, C. E., \& Gaines Jr, S. O. (1997). Prescriptive support and commitment processes in close relationship. Journal of Social Psychology Quarterly, 60, 79-90.

Darmawan, W. (2010). Potret kehidupan social ekonomi di kabupaten Indramayu: Tinjauan historis tahun 1970-2007. Jurnal Penelitian Pendidikan, 11(1).

Djohar, A. (2006). Model sosial dan upaya pemecahan masalah trafficking anak untuk tujuan dilacurkan: Studi kasus komunitas Desa Amis, Kecamatan Cikedung, Kabupaten Indramayu. (Tesis). Universitas Indonesia, Depok.

Drigotas, S. M., Rusbult, C. E., \& Verette, Z. E. (1999). Level of commitment, mutuality of commitment, and couple well being. Personal Relationship, (6), 389-409.

Ehrenberg, M. F., Robertson, M., \& Pringle, Z. (2012). Attachment style and marital commitment in the context of remarriage. Journal of Divorce and Remarriage, 53, 204-219.

Fadlyana, E., \& Larasaty, S. (2009). Pernikahan usia dini dan permasalahannya. Sari Pediatri, 11(2), 136-140.

Farida, I. (2001). Pengaruh kepuasan dengan pasangan, kualitas alternatif, dan investasi yang telah dikeluarkan terhadap komitmen suami dalam perkawinan. (Skripsi). Universitas Indonesia, Depok.

Fauzi, A. (2014). Eskalasi Perceraian di Lingkungan TKI Masyarakat Pulau Kangean, Kabupaten Sumenep. (Skripsi). UIN Maulana Malik Ibrahim, Malang.

Firdaus, F. (2008). Hubungan tipe kepribadian dan komitmen perkawinan dengan pemaafan terhadap kebohongan pada 
pasangan dalam perkawinan Bugis. (Tesis). Yogyakarta: Universitas Gadjah Mada.

Follingstad, D. R., Rogers, M. Z., Duvall, Z. L. (2012). Factors predicting relationship satisfaction, investment, and commitment when women report high prevalence of psychological abuse. Journal of Family Violence, 27, 257-273.

Frisco, M. L., Muller, C., \& Frank, K. (2007). Parents' union dissolution and adolescents' school performance: Comparing methodological approaches. Journal of Marriage and Family, 69, 721 - 741.

Gaine, G. S., \& LaGuardia, Z. G. (2009). The unique contributions of motivations to maintain relationship and motivations toward relational activities to relationship well being. Motiv. Emot., 33, 184-202.

Givertz, M., Segrin, C., Hanzal, A. (2009). The association between satisfaction and commitment differs across marital couple types. Communication Research, 36(4), 561-584.

Hakim, A. L. (2003). Perceraian di kalangan kaum migran: Penelitian di 4 desa di Kabupaten Tulung Agung, Jawa Timur. (Tesis). Universitas Gadjah Mada, Yogyakarta.

Hango, D. W., \& Houseknecht, S. K. (2005). Marital disruption and accidents/injuries among children. Journal of Family Issues, $26,3-31$.

Hapsari, B. T., \& Iqbal, F. (2011). Komunikasi suami istri dalam mengatasi konflik pada pasangan suami istri bercerai (Studi kasus pasangan suami istri bercerai di Jakarta, Surabaya, dan Yogyakarta). Jurnal Pemikiran Islam, 7(2).

Imelda, N. (2004). Hubungan antara komitmen perkawinan dengan tingkat pemafaan pada istri yang merasa disakiti. Depok: Universitas Indonesia.

Impett, E. A., Beals, K.A., \& Peplau, L. (2001). Testing the investment model of relationship commitment and stability in a longitudinal study of married couples.
Journal of Current Psychology, 20, 312326.

Jones, G. W., Asari, Y., \& Djuartika, T. (1994). Divorce in West Java. Journal of Comparative Family Studies, 25(3), 395416.

Jones, W. H., Adams, Z. M., Monroe, P. R., \& Berry, Z. O. (1995). A psychometric exploration of marital satisaction and commitment. Journal of Social Behavior and Personality, 10(4), 923-932.

Kasim, S. (2010). Budaya Dermayu: Nilai-nilai Historis, Estetis, dan Transendental. Yogyakarta: Pustaka Djati.

Khumas, A. (2012). Model Penjelasan Intensi Cerai Perempuan. (Disertasi). Universitas Gadjah Mada, Yogyakarta.

Koentjaraningrat. (1984). Kebudayaan Jawa. Jakarta: Balai Pustaka.

Lewthwaite, B. (2011). Applications and Utility of Urie Bronfenbrenner's Bio-ecological Theory. Kanada: Manitoba Education Research Network.

Nazarudin, P. (1998). Makna Kawin Muda dan Perceraian: Upaya Memahami Masalah dari Perspektif Penyandang Masalah, Studi di Kecamatan Kandanghaur, Indramayu. (Tesis). Universitas Indonesia, Depok.

Nelson, Z. A., Kirk, A. M., Ane, P., \& Serres, S. A. (2011). Religious and spiritual values and moral commitment in marriage: Untapped resources in couples counselling? Counseling and Values, 55, 228-246.

Ningsih, E. Y., \& Handoyo, P. (2015). Perjodohan di masyarakat Bakeong, Sumenep, Madura (Studi fenomenologi tentang orang tua menjodohkan anak). Paradigma, 3(3), 1-5.

Peddyastri, T. P. (2005). Stres dan coping dalam mempertahankan pernikahan pada pasangan dengan suami yang memiliki cacat fisik. (Skripsi). Universitas Indonesia, Depok.

Prianto, B. Wulandari, N. W., Rahmawati, A. (2013). Rendahnya komitmen dalam perkawinan sebagai sebab perceraian. Jurnal Komunitas, 5(2), 208-218. 
Rahmatika, N. S., \& Handayani, M. M. (2012). Hubungan antara bentuk strategi coping dengan komitmen pernikahan pada pasangan dewasa madya dual karir. Jurnal Psikologi Pendidikan dan Perkembangan, 1(3).

Rosadi, I. (2010). Konsekuensi migrasi internasional terhadap relasi gender (Studi tentang buruh migran internasional yang telah pulang kembali kepada keluarganya di Kecamatan Juntinyuat, Kabupaten Indramayu, Jawa Barat). (Disertasi). Universitas Indonesia, Depok.

Situmorang, A. (2005). Staying single in married world: The life of never married women in Yogyakarta and Medan. Asian Research Institute Working Paper, 38, 123.

Smith-Hefner, N. Z. (2005). The new Muslim romance: Changing patterns of courtship and marriage among educated Javanese youth. Journal of Southeast Asian Studies, 36(3), 441-459.

Soedijar, A. (2004). Faktor pendukung terjadinya perdagangan perempuan dan anak di daerah asal (Studi kasus di Kabupaten Indramayu). Jakarta: Badan Pelatihan dan Pengembangan Sosial, Departemen Sosial RI.

Soekarba, S. R., \& Kenyowati, E. (2011). Tragedi cinta dan rumah tangga dalam lirik lagu Tarling Indramayuan: Studi kasus terhadap lirik lagu Tarling Indramayan. Yogyakarta: Prosiding International Conference on Indonesian Studies.

Suhardono, E. (1998). Model teori pengambilan keputusan krisis pernikahan: Suatu kajian pada klien konseling pernikahan di beberapa kota di Jawa. (Tesis). Universitas Indonesia, Depok.

Suhartini, E. (2013). Peran wanita nelayan di dalam keluarga, rumah tangga, dan masyarakat Madura, Jawa Timur. Jurnal Inspirat, 5.

Sun, Y., \& Li, Y. (2002). Children's well-being during parent's marital disruption process: A pooled time-series analysis. Journal of Marriage and Family, 64, 742 - 762.
Wahyuni, Y. T., \& Abidin, Z. (2015). Pengalaman hidup lansia yang mengasuh cucu (Studi kualitatif fenomenologis dengan interpretative phenomenological analysis). Jurnal Empati, 4(4), 8-14.

Wazdi, D. F. (2006). Respon perempuan terhadap program pengembangan kecamatan: Kasus PPK Kecamatan Bongas, Kabupaten Indramayu. (Tesis). Universitas Indonesia, Depok.

Wismanto, Y. B. (2004). Kepuasan perkawinan: Ditinjau dari komitmen perkawinan, penyesuaian diadik, kesediaan berkurban, kesetaraan pertukaran, dan persepsi terhadap perilaku pasangan. (Disertasi). Universitas Gadjah Mada, Yogyakarta.

\section{Internet}

Angka Perceraian di Indramayu Meningkat, diakses dari http://www.pikiranrakyat.com/jawa-barat/2018/06/26/angkaperceraian-di-indramayu-meningkat426440 pada 27 Oktober 2018.

Jumlah Penduduk Menurut Jenis Kelamin di Kabupaten Indramayu, diakses dari https://indramayukab.bps.go.id/dynamictab le/2016/08/03/16/jumlah-pendudukmenurut-jenis-kelamin-di-kabupatenindramayu-2013-2015.html pada Oktober 2018.

Masyarakat Indramayu Miskin Karena Konsumtif, diakses dari http://www.pikiran-rakyat.com/jawabarat/2016/11/11/masyarakat-indramayumiskin-karena-konsumtif-384546 pada 27 Oktober 2018. 